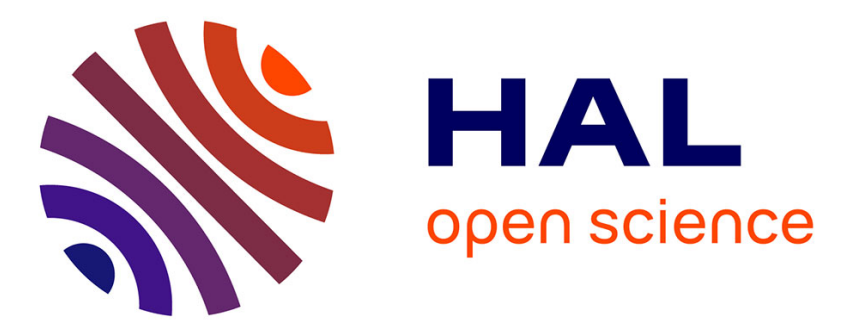

\title{
Corporate strategy and the environment: towards a four-dimensional compatibility model for fostering green management decisions
}

Fabien Martinez

\section{- To cite this version:}

Fabien Martinez. Corporate strategy and the environment: towards a four-dimensional compatibility model for fostering green management decisions. Corporate Governance: The international journal of business in society, 2014, 14 (5), pp.607-636. 10.1108/CG-02-2014-0030 . hal-02887618

\section{HAL Id: hal-02887618 https://hal.science/hal-02887618}

Submitted on 9 Jul 2020

HAL is a multi-disciplinary open access archive for the deposit and dissemination of scientific research documents, whether they are published or not. The documents may come from teaching and research institutions in France or abroad, or from public or private research centers.
L'archive ouverte pluridisciplinaire HAL, est destinée au dépôt et à la diffusion de documents scientifiques de niveau recherche, publiés ou non, émanant des établissements d'enseignement et de recherche français ou étrangers, des laboratoires publics ou privés. 


\title{
Corporate strategy and the environment: towards a four-dimensional compatibility model for fostering green management decisions*
}

\author{
By Fabien Martinez
}

\begin{abstract}
Purpose: This article draws on the contingency theory to develop a conceptual model of compatibility between corporate environmental responsibility and business strategy that reflects heterogeneity in this relationship. Four dimensions of compatibility are explored: trade-off, ambidexterity, synergy and symbiosis.
\end{abstract}

Design/Methodology/Approach: The intended contribution is essentially conceptual. A company case study is included to contribute to the development of the four dimensions of compatibility and support the practical relevance of the model. Twelve in-depth interviews with six managers in different functions of the company were conducted. A grounded theory approach was used to identify and express the patterns of compatibility that emerge from the qualitative data and how these patterns are grounded in managers' meaning-in-use.

Findings: The contribution of the compatibility framework is essentially made to the literature on environmental strategy management, evolved from an implicit and at most twodimensional (win-win and win-lose) conceptualisation of the relationship between green and business strategy into an explicit and multi-dimensionally grounded identification of processes and strategic challenges of corporate environmental and social responsibility. The resulting model contributes to a better understanding of corporate greening as a strategic and moral concern to individuals acting on behalf of business organisations and a greater understanding of the linkages between green and business strategies and operations.

Originality/Value: By clarifying the construct of corporate environmental sustainability and providing useful directions for theory and practice, this research claims to inform green management decision-making. While the compatibility model is not intended to explain all pathways by which firms may elicit contingencies of relevance to environmental and social responsibility, I suggest the model paints a more complete and contextualized picture of environmental management mechanisms in business.

Keywords - Business performance, sustainable development, corporate environmental and social responsibility, compatibility analysis

*Postprint of : Martinez, F. (2014). Corporate strategy and the environment: Towards a fourdimensional compatibility model for fostering green management decisions. Corporate Governance: The International Journal of Business in Society, 14(5), 607-636. 


\section{Introduction - the challenge of integration in business and sustainability research}

This article uses a contingency theory approach to critically examine the compatibility between corporate environmental responsibility and business strategy. Despite the acceptance by many companies of their responsibility to do no harm to the environment, decades of intense study of corporate Environmental and Social Responsibility ${ }^{1}$ (ESR), and recognition that excelling on social and environmental dimensions improves business performance (Achabou and Dekhili, 2013; Eccles et al., 2011; Margolis et al., 2007; Margolis et al., 2009; Orlitzky et al., 2003), the negative global impact of business activities on the ecosystem and communities continues to increase (Ardichvili et al., 2012) and the mechanisms for holistic ESR integration in business strategies and operations remain difficult to develop, implement and sustain (Gond and Crane, 2010; Starik and Kanashiro, 2013; Valente, 2010; Valente, 2012). I argue that part of the problem is that scholarly contributions to the study of ESR are often undertaken in isolation to the context of the firm and its overall business strategy. Synergies of scholarship pointing to the lack of a precise definition of how ESR activities relate to business strategy have accrued in recent years (see for example: Dutta et al., 2012; Etzion, 2007; Garriga and Melé, 2004; Ghoshal, 2005; Gladwin et al., 1995; Hofferberth et al., 2011; Melé et al., 2011; Swanson, 1999; Valente, 2012). For reasons that are set forth in this article, the strategic challenges of sustained superior financial performance and of competition for customers, political power, institutional legitimacy and economic fitness (DiMaggio and Powell, 1983)-widely attended to by strategic management scholars-have not fostered (or may have impeded) progress toward specifying the relationship between ESR and business performance/strategy.

One management theory that has been distinctively helpful in studies of business sustainability is the contingency perspective. The approach considers that a firm's strategic success depends on alignment within the internal business 'system' and with the external environment, with particular attention to the often conflicting needs of shareholders, customers, employees, communities, and suppliers (Smith and Lewis, 2011). Early contingency theory from the late 1960s inspired decades of research exploring how contexts influence the effectiveness of opposing and/or conflicting alternatives in strategy formation (i.e., Lawrence and Lorsch, 1967; Woodward, 1965). For example, contingency theory has been used to explore the conditions that drive choices between exploratory and exploitative *Postprint of : Martinez, F. (2014). Corporate strategy and the environment: Towards a fourdimensional compatibility model for fostering green management decisions. Corporate Governance: The International Journal of Business in Society, 14(5), 607-636. 
(Tushman and Romanelli, 1985), cooperative and competitive (Deutsch, 1968), mechanistic and organic (Burns and Stalker, 1961), and centralized and decentralized (Sigglekow and Levinthal, 2003).

ESR theorists adopting the contingency theory approach have generally attempted to address two questions: 'does it pay to be environmentally responsive?' and/or 'when does it pay to be environmentally responsive?' (Dixon-Fowler et al., 2012). As part of this agenda (or related to it), the literature dealing with the question of whether there might be a business case for sustainability helped tease out the main contingencies that produce favorable returns from ESR (see for example: Boons and Lüdeke-Freund, 2013; Malik, 2014; Salzmann et al., 2005; Schaltegger et al., 2012; Schreck, 2011). However, most of this research has sought to determine the extent to which ESR corporate behavior affects financial performance, and not the other way around. This might have contributed to create a narrow and pessimistic view of the role of business in society, a trend that Ghoshal (2005) deplored as increasingly common in business and management research. Within this view, individual managers, and by extension the firms that they run, act opportunistically (i.e. in self-interested ways and with guile) whenever possible, and therefore, are not trustworthy (Campbell, 2007).

From both a theoretical and a practical perspective, the business case for sustainability, and the win-win logic that underpins it, is problematic. The theoretical frameworks for the business case cope poorly with the complexity that firms confront in reality, and the empirical evidence that has been gathered to support it either consists of individual qualitative studies that are unrepresentative, or quantitative studies whose results are contradictory and/or inconclusive (Dixon-Fowler et al., 2012; Salzmann et al., 2005). What is more, win-win thinking frames the interrelationship between business, society and the natural environment in terms of certain issues 'overlapping' in ways that can be synergistic and beneficial in relation to the agenda of businesses and some stakeholders. Most studies of ESR in the contingency tradition have sought to legitimize the business case by arguing in favour of (and seeking to establish the contingencies of relevance to) a positive relationship between ESR and business performance (Barnett, 2007). As a result, the existence of patterns of compatibility (or incompatibility) outside the 'win-win' intersecting area, and beyond consideration of positive net results and tangible performance indicators, has been overlooked. If the failure of management theory to deliver a realistic assessment of the relationship between ESR and business strategy is partly responsible for the lack of progress in developing substantively more sustainable business and production/consumption systems

*Postprint of : Martinez, F. (2014). Corporate strategy and the environment: Towards a fourdimensional compatibility model for fostering green management decisions. Corporate Governance: The International Journal of Business in Society, 14(5), 607-636. 
(Browne and Nuttall, 2013; Fooks et al., 2013; Lorenzo-Molo and Udani, 2013; Sun and Cui, 2014), then it suggests a need to explore other approaches.

This paper aims at contributing to fill this gap by developing a new contingency framework of compatibility between green and business strategy-making that explains heterogeneity in business conception of ESR. The framework seeks to be more useful to companies by expanding our understanding of the ways in which ESR relates to business strategy in a contingent world, and potentially across different institutional environments and countries. It considers the existence of four dimensions of compatibility between ESR and business strategy drawn from the lean and green compatibility framework of Martinez et al. (2012, p. 196): trade-off, ambidexterity, synergy and symbiosis. In Martinez et al.'s model, these compatibility dimensions represent subsequent stages in an evolutionary process of organisational learning and greening. The heterogeneous relationship described by the model is viewed in this paper as unique in its explicit treatment of the various ways in which ESR relates to business strategy. It contributes as an overarching contingency framework that is well suited to account for the influence of a variety of contingent factors on ESR strategy management; whether these factors mediate a positive (symbiosis and synergy), negative (trade-off) or neutral (ambidexterity) relationship between strategy and ESR, as recognised by Waddock and Graves (1997) and as supported by the organisational complexity theory (Van de Ven et al., 2013). In the present study, I propose to (re-)orient the theoretical and practical underpinnings of the research axis explored by Martinez et al. (2012). I clarify the meaning and necessity of a compatibility framework that may help to understand and pursue a shift towards context-sensitive and sustainability-driven business practice and theory.

I begin with a brief review of the literature on ESR to identify some important clues that will help focus discussion on the way management theory frames the compatibility between ESR and business strategizing. The question of whether the heterogeneity (or variance) discussed above is covered with sufficient scrutiny in management research-and what contingency factors might have been overlooked-will be raised.

\section{Toward an extended contingency framework for business sustainability}

Models of how environments and organisations relate over time have typically assigned causal primacy to environmental forces while neglecting organisational forces such

*Postprint of : Martinez, F. (2014). Corporate strategy and the environment: Towards a fourdimensional compatibility model for fostering green management decisions. Corporate Governance: The International Journal of Business in Society, 14(5), 607-636. 
as the strategic, operational and market contexts of the firm. As a case in point, Delmas et al. (2013) propose a two-dimensional conceptualisation of environmental performance that integrates the processes that companies put in place to do 'good' and reduce future environmental impacts and the actual current negative releases that are 'bad' for the environment. They endorse a view of social and environmental ratings that distinguishes between processes and outcomes with a focus on the measurement and evaluation of four factors: environmental impacts, commitment to environmental causes, sophistication of environmental management systems and managerial quality in general. The emphasis of Delmas et al. (2013) on 'environmental indicators' might be conceived of as reminiscent of a line of thinking that emerged in the 1990s in ESR research and sought to understand the extent to which companies are willing to respond to environmental issues (e.g., are they 'proactive', 'reactive', or 'innovative'?). This generated a number of environmental strategy management typologies found in the works of, e.g., Hunt and Auster (1990); Roome (1992); Newman (1993); Müller and Koechlin (1992); and Greeno (1993). In critical reviews of these typologies, Hass (1996); and Buysse and Verbeke (2003) explain that environmental management research in general would benefit from a more contextual approach which links the environmental management response to the main business strategy of the firm and upon which sustainability-driven innovations by business might be founded. The following comment from Devinney (2009, p. 54) supports this view: "until there is a clear understanding and articulation of the domain and subdomains of corporate social responsibility, few fruitful generalizable conclusions will be possible, as every result will be contingent on the corporate and social context and the relevant 'responsibility' under investigation". Theories that accommodate the organisation's context of performance-in terms of economic, operational and strategic efficiency and effectiveness-are thus to be developed to give rise to meaningful corporate environmental sustainability strategies.

Other theorists have assigned primacy to the integration of the two forces (e.g., Barnett, 2007; Carroll and Shabana, 2010; Devinney, 2009; Porter and Kramer, 2011; Porter and van der Linde, 1995a). While some of these theories advocate the need for contextgrounded approaches to ESR integration (Barnett, 2007; Buysse and Verbeke, 2003; Carroll and Shabana, 2010), none of them clearly extend the reflection to a multi-faceted approach to ESR that accounts for different dimensions of compatibility between green and business performance at strategic and operational levels. Although some authors have proposed solutions for linking environmental responsiveness and business strategy-e.g. inside-out and

*Postprint of : Martinez, F. (2014). Corporate strategy and the environment: Towards a fourdimensional compatibility model for fostering green management decisions. Corporate Governance: The International Journal of Business in Society, 14(5), 607-636. 
outside-in perspectives (Porter and Kramer, 2006), creating shared value (Porter and Kramer, 2011), and lean and green concept (King and Lenox, 2001a; King and Lenox, 2001b; Simons and Mason, 2003); views of the process through which integrated green/business strategizing is accomplished are still lacking clarification. In fact, these views typically iterate between two advocacies: (i) one focusing on the existence of trade-offs at multiple scales (e.g., Hahn et al., 2010); and (ii) the other one, more extensively discussed, for win-win situations-an idea which reflects an approach to the effects of the environment on firm competitiveness and profitability (Kurucz et al., 2008; Porter and van der Linde, 1995a; Porter and van der Linde, 1995b). A proposition in this study is that these two advocacies are not opposed to each other. Instead they are intertwined within one framework of ESR integration that explicitly acknowledges the existence of different dimensions of compatibility between ESR and business economic, operational and strategic efficiency and effectiveness.

A contingency perspective is arguably well suited to support this proposition because it recognizes heterogeneity in business returns to/from ESR (Barnett, 2007). However, a theoretical framework that explicitly captures and represents heterogeneity (or variance) in the compatibility between ESR and business strategy-making is lacking in management theory. At the origins of the contingency view, strategy was mainly conceived of as a long-term rational plan intended to create value (Ginsberg and Venkatraman, 1985). Decision-making was primarily based on statistically significant results; the representativeness and validity of which was criticised in marketing research (Sawyer and Peter, 1983). Still within the early contingency view, efforts of individual agents of management to deal rationally with uncertainty and constraints often led, in the aggregate, to homogeneity in structure, culture, and output (DiMaggio and Powell, 1983; Van de Ven et al., 2013). The influence of the values and perceptions of top managers on organizational strategy and effectiveness tended to be discarded (Hambrick and Mason, 1984). A stream of contemporary research work into business sustainability suggests that these patterns have endured over decades of business practice and theories that have failed to deliver realistic and useful solutions for both companies and society (e.g., Browne and Nuttall, 2013; Fooks et al., 2013; Lorenzo-Molo and Udani, 2013; Sun and Cui, 2014). The instrumental and deterministic rationale that has long prevailed (and still prevails) in industrial society in general, and environmental strategy management in particular, is based on elements such as efficiency gains and the mastery of technological innovation over nature that appear to be insufficient on their own to avert (and

*Postprint of : Martinez, F. (2014). Corporate strategy and the environment: Towards a fourdimensional compatibility model for fostering green management decisions. Corporate Governance: The International Journal of Business in Society, 14(5), 607-636. 
perhaps reverse) the negative impact of individual and collective (business) enterprises on society (Murphy, 2004; Starik and Kanashiro, 2013). The results of a survey of over a thousand managers in eight international firms conducted by Pedersen (2010) suggest that managers still have a relatively narrow perception of societal responsibilities, which can be summarized as follows: take care of the workers and make the products and services that the customers want in an environmentally friendly way. The lack of breadth in our practical and theoretical conception of ESR in business is also captured in Shelton's (1994) notion of the "Green Wall". The underlying idea is that the challenge of ESR integration extends beyond energy and waste disposal cost savings to encompass the need to attune ESR with corporate culture and other drivers for strategy formation such as behavioural/cognitive aspects (Peattie, 2001; Shelton, 1994). The challenge of unraveling the 'hidden connections' between human activities (including business) and societal issues (Capra, 2002)-or uncovering and integrating the nearly obvious, as Starik and Kanashiro (2013) put it-arguably requires fostering the development of novel and more 'context-sensitive' frameworks and theories. Research efforts in this sense might enable us to reduce (or bridge) the distance observed by Jabbour et al. (2008) between what is recommended by international literature and the reality of companies in the challenge of, e.g., making the production function environmentally friendly. More context-sensitive framework and theories might also help companies, investors, academics and policy-makers understand how to finance the transition to (and the financial incentives of) a more sustainable global economy and society as one of the major challenges raised at the 2013 ABIS Annual colloquium 'Sustainability and Finance'.

Some scholars argue that one of the major challenges towards a more context-sensitive framework is that our understanding of business decision-making (particularly on ESR) is disserved by a latent separation of facts from values in both business practice and theory (Dienhart, 2008; Harris and Freeman, 2008). The trend has been for theorists to suggest and managers to enact an approach made popular by Nobel Prize winning Milton Friedman (1970) that views business decisions as if there are no moral consequences to them. Within this view, unfettered profit maximization is the single objective function of business firms and corporate responsibility is limited to increasing shareholder wealth (Bowie, 2013). The notion of a 'separation' between business decisions and ethical decisions is widely contested (e.g., Harris and Freeman, 2008; Jensen and Sandström, 2013). Because the separation thesis "incalculates a societal narrative about business and ethics in which ethical considerations are

*Postprint of : Martinez, F. (2014). Corporate strategy and the environment: Towards a fourdimensional compatibility model for fostering green management decisions. Corporate Governance: The International Journal of Business in Society, 14(5), 607-636. 
no less real, but merely devalued and denatured" (Harris and Freeman, 2008, p. 543), its application to management practice and theory might have constituted an impediment to the development of sustainability-driven principles in business. Within this view, corporate managers and their employees are one-dimensional maximizers of self-interest with convex utility functions for monetary wealth (Harris and Freeman, 2008). In this article, I develop a more nuanced treatment of moral values within organization theory and strategic management. The argument is that the firm is not merely an economic actor that speaks only through its economic power in a context defined by the laws of the market but also a social actor whose moral sphere includes consideration of a multiplicity of goals related to economic health, social equity and ecological integrity (Jensen and Sandström, 2013).

\section{The 'EFF-squared' assumption}

Such a distinctively 'ethical' contingency approach can arguably be built upon the assumption that business strategizing depends on what business actors (leaders, staff) conceive to be both the right thing to do (effectiveness) and the right way to do things (efficiency)-consistent with the definition of the efficiency and effectiveness concept by Drucker (1954). In this article, I choose 'EFF-squared' as the label for combined efficiency and effectiveness. Porter's (1985) value chain and the concept of lean and green (King and Lenox, 2001b; Simons and Mason, 2003) both integrate efficiency (time compression, cost reduction) and effectiveness (value enhancement) as key performance indicators for companies. The EFF-squared concept has been expressed-less explicitly-in the works of early strategy authors such as Drucker (1954), Lewin (1951), Reddin (1970) and Ackoff (1988). EFF-squared is determined relative to one or more targets or output requirements (Ackoff, 1988; Reddin, 1970). While the value of these targets is not relevant to the determination of efficiency, it is relevant to the determination of effectiveness (Ackoff, 1988).

An 'efficiency versus effectiveness' matrix is presented in Figure 1. It suggests that efficiency is determined by the journey-i.e. time and innovation (as the evolution of knowledge and product/service quality within a company) or experience and learning (doing the same old thing over and over again but with gradually increasing efficiency)-and effectiveness relates to the nature of the target. The matrix integrates different scenarios abbreviated as $\mathrm{EFF}^{2}, \mathrm{EFF}^{(-2)}$ and (in) $\mathrm{EFF}^{2}$ that are explained in the discussion below.

*Postprint of : Martinez, F. (2014). Corporate strategy and the environment: Towards a fourdimensional compatibility model for fostering green management decisions. Corporate Governance: The International Journal of Business in Society, 14(5), 607-636. 
[Insert Figure 1 about here]

In line with the concept introduced by Drucker (1954) and the absorptive capacity theory (Cohen and Levinthal, 1990), the determination of efficiency and effectiveness is understood to be linked to three characteristics: (i) the firm's capacity to build awareness, (ii) the ability to identify the target (e.g. customer satisfaction or societal/environmental responsibility?) and (iii) the ability to understand the implications this holds for business efficiency as the journey to achieving the target. With this insight, business operations, units or divisions may be designed or redesigned more effectively.

The notion of effectiveness in strategy-making is essentially about the future (Kaplan and Orlikowski, 2007). A manager's conception of EFF-squared is understood to mirror his/her choice of strategic actions to achieve competitive advantage in the short or long-term. According to Kaplan and Orlikowski (2007), the choice of strategic actions is made by projecting into the future both in terms of possible trajectories (managers' diagnosis) and potential resolutions (managers' prognosis). These projections are critically shaped by the past. Managers draw on and use repertoires of accumulated knowledge. These repertoires both capture their attention and shape their interpretations of the current situation. They can be recurrently reproduced thus acquiring structural properties; therefore, the strategy-making process can be quite routinized. Managers may also act creatively to produce new interpretations and new decisions; particularly in response to changes in the environment. Such changes may unsettle or break routines and frames and create an opening for problematisation of the situation in a new way, for actors to draw on the repertoires differently than in the past and to project new trajectories for the future. Consistent with Kaplan and Orlikowski (2007), I argue that the determination of EFF-squared depends partly on both the timescale managers consider and the salience that is associated with the impact of environmental trends on business activities.

Braungart and McDonough (2008, p. 65) argue that efficiency can be valuable "when implemented within a larger, effective system that intends overall positive effects on a wide range of issues-not simply economic ones". The implication is that an effective strategic vision determines the disaggregation of efficiency. For example, eco-effective visions may encourage companies to commit to a new paradigm that signals intention founded on 'ecofriendly' principles (Braungart and McDonough, 2008; Young and Tilley, 2006). Braungart and McDonough (2008, p. 182) give an example: "when a business leader says, 'we are going

*Postprint of : Martinez, F. (2014). Corporate strategy and the environment: Towards a fourdimensional compatibility model for fostering green management decisions. Corporate Governance: The International Journal of Business in Society, 14(5), 607-636. 
to make a solar-powered product,' that is a signal strong enough for everyone to understand the company's positive intentions, particularly since total and immediate change is difficult in a market dominated by status quo". Eco-effectiveness may thus enable us to disaggregate efficiency into a number of components that are related to economic and environmental capital. I thus propose an overall concept of combined green ${ }^{2} /$ business efficiency. An ecoeffective company may thus propose to optimise the compatibility between green and EFFsquared by minimising pollution. This particularly links to Porter and van der Linde's (1995a; 1995b) argument that all pollutions represent a form of inefficiency.

In elaborating on the rationale for linking efficiency and effectiveness, Mouzas (2006, p. 1127) explains that both a focus on efficiency and a neglect of effectiveness may generate "ephemeral profitability" (as shown in Figure 1). His empirical work indicates that, in many international companies, business managers focus on producing efficiency gains (Mouzas, 2006). In the same vein, Gladwin et al. (1995) indicate that the body of management theory emphasises what works (efficiency) over what is worth pursuing (effectiveness). This bias towards business efficiency may conspire against business objectives of differentiation and sustainable growth (Gladwin et al., 1995; Levitt, 2004; Mouzas, 2006). As a case in point, the Enron scandal may partly be explained as the result of a focus of top management on shortterm gains "at any cost" (Petrick and Scherer, 2003, p. 38). Enron's business model inhibited well-intentioned employees from doing the right thing (i.e. effectiveness) and turned out to be unsustainable and illegal (Petrick and Scherer, 2003). Referring to the Ford manufacturing checklist for mass production, efficiency is traditionally designed to increase power, accuracy, economy, system, continuity and speed (Braungart and McDonough, 2008). It relies on a seemingly endless supply of natural capital for making and delivering a product to a customer quickly and cheaply without considering much else (Braungart and McDonough, 2008). Peattie and Charter (1997) indicate that the argument of efficiency bias as anti-catalyst to sustainable growth was popular in the mid-late 1980s. It was a reaction to the 'efficiencybased' strategies of the 1970s which were themselves a reaction to the oil shocks of the first half of that decade (Peattie and Charter, 1997). This historical note is well suited to highlight how a company's conception of EFF-squared relates to the environmental and socioeconomic contexts of the firm.

The reverse pattern discussed by Mouzas (2006) consists of focusing on effectiveness and neglecting efficiency. This generates "unprofitable growth" if the opportunity cost of 
capital is higher than the resulting profit (Mouzas, 2006, p. 1127). The conclusion of Mouzas (2006) is twofold: (i) companies are to view efficiency as a necessary, yet insufficient, condition for sustainable growth; (ii) companies are to consider effectiveness not as an absolute output but as a continuous process impacting on their surrounding networks. He hence advocates a balanced approach that aims at high efficiency and high effectiveness as a means to pursuing "sustainable growth" (Mouzas, 2006, p. 1127). Sustainable development, according to Buysse and Verbeke (2003); and Hart (1995) requires a long-term vision shared among all relevant stakeholders and strong moral leadership propounding "healthy principles" (Braungart and McDonough, 2008, p. 183).

If, by contrast, companies operate inefficiently and ineffectively-i.e. (in)EFF-squared; the interpretation may be that they are in decline, the result of which can be their demise if they operate in a dynamic and competitive market. Weitzel and Jonsson (1989) define decline in organizations as to move through different stages amongst which a failure to anticipate or recognise the deterioration of business performance and the need for change. This signals impaired effectiveness. Ineffective organisations are less perceptive than effective ones; their difficulties in business may cause them to be excessively inwardly focused. Another stage of decline consists of organisations taking inappropriate or faulty actions or failing to stop the progress of decline (Weitzel and Jonsson, 1989). This signals inefficiency. Organisations which fail to adjust their strategies and operations to their environment, Audretsch (1995) contends, are confronted with a lower likelihood of survival in changing and highly innovative environments. The achievement of a balanced EFF-squared approach that fosters sustained growth depends on how broadly companies define the scope of their activities and, notably, how carefully managers gauge customers' needs (Levitt, 2004).

In summary, the above discussion converges on the scholarly assumption that the EFF-squared rationale might be a logical aspiration for businesses seeking to respond to changing environments and achieve sustainable growth (Audretsch, 1995; Dyllick and Hockerts, 2002; Levitt, 2004; Mouzas, 2006; Weitzel and Jonsson, 1989; Young and Tilley, 2006). It is suggested to provide for a conceptualisation of business strategy that refutes the idea of a separation between business and ethics. Patterns of actions in response to environmental issues are argued to depend on the importance granted by businesses (and the individual agents who work in them) to green and how they interpret the EFF-squared concept across a firm's primary and secondary activities (Porter, 1985). Human factors such as

*Postprint of : Martinez, F. (2014). Corporate strategy and the environment: Towards a fourdimensional compatibility model for fostering green management decisions. Corporate Governance: The International Journal of Business in Society, 14(5), 607-636. 
knowledge absorptive capacities, normative (and moral) commitment of business agents are often discussed to determine a firm's responsiveness to environmental issues (e.g., Cho, 1994; Cohen and Levinthal, 1990; Dwyer, 2009; Pane Haden et al., 2009; Pfeffer, 2010; Pursey and Heugens, 2006; Tinsley, 2002).

\section{A four-dimensional compatibility model}

The conceptual model developed in this paper proposes that, in the quest for enhanced business efficiency and effectiveness, the importance of green to the firm is multidimensional; an assertion that has received some support from other studies of corporate societal responsiveness (e.g., Buysse and Verbeke, 2003; Devinney, 2009). Therefore companies are to consider the existence of different dimensions of operational (e.g. financial, logistical) and normative (perceptions of business agents) compatibility (Tornatzky and Klein, 1982). This article provides a synthesis of the key points that characterise different patterns of compatibility and guide towards the development of a distinct contingency framework of ESR integration that yields plausible solutions and questions for future environmental strategy management research. The critical literature review supports the view that the compatibility between green and both the effectiveness and efficiency of businesses might be framed in the four scenarios envisioned by Martinez et al. (2012): trade-off, ambidexterity, synergy and symbiosis. Figure 2 shows the (symbolic) patterns assigned to each dimension in this article and adapted from Martinez et al. (2012, p. 196). The research items reviewed are essentially drawn from studies of the link between CFP and ESR (operational/practical compatibility) in which implications for business strategy are discussed; and of intangible variables such as managers' perceptions, business reputation, leadership context, etc (normative/cognitive compatibility). Table 1 specifies the type of research design adopted (conceptual, qualitative and/or quantitative) in these studies. Thus readers can distinguish between facts, suggestions and assumptions in the discussion.

[Insert Figure 2 about here]

[Insert Table 1 about here]

Trade-off. Trade-off exists when green and business performance are conflictive (Martinez et al., 2012). It is a stage of relative incompatibility between green and EFF-squared which *Postprint of : Martinez, F. (2014). Corporate strategy and the environment: Towards a fourdimensional compatibility model for fostering green management decisions. Corporate Governance: The International Journal of Business in Society, 14(5), 607-636. 
contests the assumption that economic, environmental and social aspects are mutually reinforcing. Walley and Whitehead (1994, p. 46) comment: "responding to environmental challenges has always been a costly and complicated proposition for managers; [...] win-win situations ... are very rare and will likely be overshadowed by the total cost of a company's environmental program". Colby et al. (1995) highlight the cost of ESR. They explain that, while some environmental issues may be easily resolved, trade-offs are concerned with the emergence of other environmental challenges and necessary concomitant expenses.

Porter and Kramer (2006, p. 84) point to the tendency of businesses to perceive negative correlations or the "friction" between business performance and ESR. Boyle et al. (1997); and Wright and Ferris (1997) can be cited among the studies reporting a negative relationship between corporate social or environmental performance and financial performance. The rationale is that green constrains the firm's capacity to effectively achieve its financial objectives, thereby creating an $\mathrm{EFF}^{(-2)}$ effect (i.e. hypothetically efficient yet ineffective). An assumption drawn from Lohmann (2009) is that the internalisation of external costs often leads to trade-off situations although these cost reflect distortions in the market that tend to be accepted as normal. Hahn et al. (2010) observe that trade-offs between business economic and environmental performance have not been extensively examined in the management literature. Deeper understanding of trade-offs-via conceptual and empirical explorations-is commended by Margolis and Walsh (2003) in order to clarify the relationship between economic and non-economic aspects of corporate activities.

In trade-off situations, it is impossible to achieve two or more divergent objectives simultaneously. A gain in one dimension incurs a loss in other dimensions (Hahn et al., 2010). For example, Rothenberg et al. (2001) found a negative relationship between lean management practices and reduction of air emissions of volatile organic compounds $\left(\mathrm{VOC}^{3}\right)$. They also explain that lean plants are sometimes driven to compromise some of their lean management principles in order to reduce their emissions. In Japan, for instance, plants have altered their 'just-in-time' delivery system to reduce congestion and urban air pollution (Cusumano, 1994). In the same vein, Cruz Machado and Duarte (2010) question the ESR advantages of lean principles. They note that, while lean principles 'prescribe' that distances on a firm's supply chain should be as short as possible, an increasing number of MNCs are taking advantage of the low cost of labour in developing countries where production sites are implemented. Therefore transportation links are lengthened and the environmental impact is 
likely to be stronger. Trade-off implies that business strategies intended to enhance operational efficiency and effectiveness such as those that are inspired by 'lean thinking' can delay, prevent or debase green performance.

In exploring the general concept of sustainable economics, Goerner et al. (2009) acknowledge the existence of trade-offs between ESR and the efficiency and resilience of the economic system. They comment: "blind obsession with GDP growth, efficiency and maximising profit for owners regardless of the costs to anyone or anything else set neoliberal economics at odds with workers, consumers, small business and the environment" (Goerner et al., 2009, p. 81). Hahn et al. (2010) stress the key role of individual decision-makers in contributing to trade-off situations. The argument is that the perceptions, motives, values and decisions of single actors within an organisation may act as triggers for the construction of bias or conflicts of interest vis-à-vis environmental performance. This refers to situations where, e.g., individuals' self-advancement or quest for self-actualisation (including pecuniary or hierarchical promotion) within a firm has a pernicious influence on their decisions regarding ESR performance. McCrea (2010, p. S60) explains that "perceptions that green is a transient strategy, or one that will cost an awful lot of money, for example, tend to stand in the way for many shippers-despite their supply chain manager's good intentions"-a pattern captured by Petrick and Scherer (2003) in their analysis of the Enron scandal. This negative approach to green may translate into low absorptive capacity with regard to environmental innovation (Cohen and Levinthal, 1990). The 'pay-off' timescale accepted at managerial level may determine a firm's absorptive capacity and the relevance of ESR. Companies willing to accept short-term pay-offs may perceive green as incompatible with EFF-squared (Hahn et al., 2010; Siegel, 2009) under the assumption that green requires significant investments and produces long-term financial returns.

Hahn et al. (2010) contend that trade-offs are to be accepted as the 'normative' premise upon which substantial sustainability or ESR benefits may flourish. Porter and van der Linde (1995b); and Orlitzky (2005) contest this rationale arguing that framing environmental improvement as involving a systematic trade-off between social or green and private benefits is incorrect. They consider that the idea of a programmatic struggle between ecology and the economy emanates from a static view of environmental contingencies in which technology, products, processes and customer needs are fixed entities (Porter and van der Linde, 1995b). The development of integrated green/EFF-squared approaches arguably rests not on optimising within fixed constraints but on the capacity to shift the constraints

*Postprint of : Martinez, F. (2014). Corporate strategy and the environment: Towards a fourdimensional compatibility model for fostering green management decisions. Corporate Governance: The International Journal of Business in Society, 14(5), 607-636. 
through innovation and improvement (Huczynsky and Buchanan, 2007; Mouzas, 2006; Porter and van der Linde, 1995b). This challenges the case for trade-offs as the normative approach and implies that a broader scope of analysis accounting for innovation and improvement capabilities may be required. In line with Usunier et al. (2011), business operations may be assigned ESR integration scenarios wherein green and EFF-squared are (or perceived to be) compatible. This follows the idea of "moving beyond trade-offs" to envision opportunities for shared value creation (Porter and Kramer, 2011, p. 64). In this article, I enlarge the scope of analysis to incorporate three additional dimensions of compatibility: ambidexterity, synergy and symbiosis (Martinez et al., 2012).

Ambidexterity. A recurring argument in a variety of management literatures is that successful organisations in a dynamic environment are ambidextrous. The notion of strategic ambidexterity relates to the simultaneous capacity of an organisation to be aligned and efficient in managing business demands and to be adaptive enough to changes in the environment (Duncan, 1976; Tushman and O'Reilly, 1996). Tushman and O’Really (1996) explain that ambidextrous organisations are needed to operate part of the time in a world characterised by periods of relative stability and incremental innovation, and part of the time in a world characterised by revolutionary change. They suggest that ambidexterity may require that exploitation-i.e. efficiency, increasing productivity, control, certainty and variance reduction-and exploration-i.e. search, discovery, autonomy, innovation and embracing variation-are pursued simultaneously, with separate subunits, business models and distinct alignments for each (Tushman and O'Reilly, 1997). Ambidexterity, in the context of strategic change and new product development, requires not only separate structural subunits for exploration and exploitation but also different competencies, systems, incentives, processes and cultures-each internally aligned (O'Reilly and Tushman, 2008).

In reflecting on the compatibility between green and EFF-squared, one interpretation of ambidexterity is that it consists of establishing separate environmental/sustainability structural sub-units and building adapted competencies, systems, incentives, processes and cultures for ESR integration. A separate business unit, run by a Chief Sustainability Officer (CSO), may bridge departmental rivalries and contribute to the promotion of a view of sustainability as integral to the business principles of the organisation (McNulty and Davis, 2010). To this argument, McNulty and Davis (2010, p. 137) counterpoise the assertion that seeking to provide ESR by "adding another layer of bureaucracy in the form of a CSO is not *Postprint of : Martinez, F. (2014). Corporate strategy and the environment: Towards a fourdimensional compatibility model for fostering green management decisions. Corporate Governance: The International Journal of Business in Society, 14(5), 607-636. 
the answer". It may generate organisational silos and internal boundaries within which knowledge, expertise and resources are confined, hence difficult to transfer across the company (Gulati, 2007). To transcend these barriers and embark on "silo-busting" (Elkington, 2004, p. 14; Gulati, 2007), ESR integration should instead be the job of CEOs. McNulty and Davis (2010) enumerate four reasons to explain why CEOs are competent to do this. First, CEOs have more influence within the company to champion and effect positive change. Second, they would better mobilise suppliers and reassure customers. The third reason is that CEOs are more accountable to the board of directors, shareholders, government policy makers and nongovernmental organisations. They would finally have better insight into the relationship between sustainability and corporate strategy and vision. Pujari, Peattie, and Wright (2004) corroborate the importance of top management support in proactively integrating environmental issues at product development level. Strategic decisions relating to environmental responsiveness and product development include financial analysis and market assessment to determine resource commitments, identification of target markets and initial go/no go decisions. These decisions all require senior management involvement and approval to progress. While ambidextrous strategies-such as the decision to hire a CSO-may be envisaged to demonstrate awareness to ESR matters, they may reduce the scope of business opportunities for achieving growth and gaining competitive advantage (McNulty and Davis, 2010).

The notion of ambidexterity has never been explicitly examined as a scenario of compatibility between green and business strategy. The debate around the concept of strategic ambidexterity mainly revolves around the processes of strategy formation and execution. While this debate informs the above discussion of sustainability sub-units, it copes poorly with the present attempt at identifying a scenario of neutral compatibility between green and EFF-squared. A different conception of ambidexterity can be found in Kollman and Stockman (2008); Vazquez-Brust et al. (2009) and Martinez et al. (2012). They define it as the state of being equally adept in the advancement of both economic and environmental performance. The literature on ESR reveals at least two plausible matches for this definition of ambidexterity; one between green and consumption, the other one between green and financial performance. In contrast to the idea that sales performance may be boosted by green credentials (Russo and Fouts, 1997; Siegel, 2009), Valor (2008)-later echoed by Carroll and Shabana (2010)-argues that consumers are not able to buy responsibly because it is a time consuming activity, economically disadvantageous and stressful. The implication is that a

*Postprint of : Martinez, F. (2014). Corporate strategy and the environment: Towards a fourdimensional compatibility model for fostering green management decisions. Corporate Governance: The International Journal of Business in Society, 14(5), 607-636. 
company may be able to sell its products/services to consumers while simultaneously improving its environmental performance without a correlation between these two activities. In the same vein, a number of studies have found a relatively minor correlation between corporate social and environmental performance and the financial performance of a firm (see for example: Aupperle et al., 1985; Guerard, 1997; Ullman, 1985).

The idea of ambidexterity is thus explored in this article within a compatibility framework to challenge the assumptions that green and EFF-squared tend to either conflict (via trade-off) or be mutually reinforcing. It suggests that, under certain specified circumstances, it may be possible for organisations to pursue both green and economic performance with no significant relationship between them. The ambiguities of ambidexterity are about whether it is achieved sequentially or in parallel, at the business unit or organisational level, or how exactly these skills are acquired. By appropriating the idea of ambidexterity within the compatibility framework, future research may specify the nature of ambidextrous scenarios.

Synergy. Synergy implies a catalytic effect between green and business performance in a mutually beneficial relationship (Martinez et al., 2012). Initiatives to improve one variable generate or inform opportunities for improvement in the other variable. Applications of metaanalysis (Margolis et al., 2007; Margolis et al., 2009; Orlitzky et al., 2003), and other extensive empirical inquiries (Waddock and Graves, 1997), showed robust evidence of the positive relationship between ESR and financial performance.

Margolis and Walsh (2001) describe some of the economic benefits that are linked to ESR: reducing pollution can reduce operational costs, complying with environmental standards facilitates process innovation, and developing strategies for the management of scarce resources (water, energy) reassure investors (procurement security). For example, the 'common threads' program implemented by the garment company Patagonia (2005) generates synergistic effects through, e.g., the use of alternative energy in transportation and the development of recycling technologies and operations. These initiatives increased the efficiency of production processes while substantially reducing the firm's environmental footprint (for a detailed environmental analysis, see: Patagonia, 2005). While such green/EFFsquared 'synergies' may be explored and exploited by businesses, they arguably fail to explain the full potential of ESR activities. Shelton (1994)-echoed by Peattie (2001)-draws from the case of Apple, Warner-Lambert and $\mathrm{ABB}$ to suggest that green/EFF-squared 
synergies based around cost-saving projects which save energy or reduce waste disposal costs (e.g. packaging reduction) constitute a basic yet relatively low level of ESR integration. The impact of these initiatives is metaphorically referred to as "low-hanging fruits" (Peattie, 2001, p. 137; Shelton, 1994). Once these 'fruits' have been picked and further environmental improvement require more radical changes, the greening process begins to clash with corporate culture and other corporate strategies and vested interests (Peattie, 2001; Shelton, 1994). Robèrt (2002) discusses the case of a Swedish McDonald's who switched from plastic covers on their hamburgers to paper covers with a view to improving their environmental performance. The change did not live up to the firm's expectations since it caused more environmental harm and consolidated McDonald's reputation of ecological laggard and of a firm with only commercial interests. The gap between intentions and outcomes found in this case is explained by Robèrt (2002) to stem from a lack of awareness and integration of ESR at deeper managerial level.

The realisation of green/EFF-squared synergies may also emerge from transient strategies and initiatives intended to signal good corporate citizenship (McCrea, 2010). Referred to by Shelton (1994) as "hitting the Green Wall", this approach might be associated with opportunistic behaviours-i.e. "self-interest seeking with guile" (Williamson, 1985, p. 47). It follows that synergistic compatibilities may not be sufficient on their own to explain the business case for sustainability. This suggestion provides a rationale for examining another scenario of compatibility in which EFF-squared is more intrinsically linked to green: symbiosis.

Symbiosis. The notion of symbiosis reflects the assumption that ESR integration is mediated to a significant extent by intangible factors such as corporate culture, visionary leadership, behavioural aspects, reputation management, etc. Managers' perception of the importance of green may generate a vision of green/EFF-squared symbiosis. The works of Sully de Luque et al. (2008); and Waldman and Siegel (2008) shed light on the role of strategic leadership and top management in acting as change agents, building strong stakeholder values and inspiring high levels of concern for environmental issues. For example, the founder of the BodyShop Anita Roddick $(2000 ; 2003)$ described her attempt to 'heal' the perceived divisions between work and community, between ethics and economics in the company by empowering people and managing business from the heart-a form of constructionist logic that I frame in this article into the concept of symbiosis.

*Postprint of : Martinez, F. (2014). Corporate strategy and the environment: Towards a fourdimensional compatibility model for fostering green management decisions. Corporate Governance: The International Journal of Business in Society, 14(5), 607-636. 
Symbiotic relationships between ESR and business performance may emerge from the way companies respond to a variety of broader pressures and/or strategic challenges across different institutional environments and countries (Campbell, 2007), such as those associated with the evolution of regulations and market fluctuations. While the emergence of market failure and related social $\operatorname{cost}^{4}$ can justify government intervention, at the symbiosis level, companies choose to anticipate or go beyond environmental regulations to provide ESR (Reinhardt and Stavins, 2010; Siegel, 2009) because they advocate a philosophically different approach to business, driven by non-traditional market forces, guided by non-traditional business practices, and incentivised by both financial and societal aims (Scholl, 2013). Symbiosis feeds into the formula, adapted from Reddin (1970), which contends that efficiency is the ratio of effectiveness to societal value; that is, in mathematical terms, efficiency $=$ effectiveness $/$ societal value.

An illustration will perhaps be helpful for an organisation attempting to categorise what it has done according to the four-dimensional compatibility model. BRECO (a pseudonym) is a British regional Brewery founded in $1890^{5}$. In the wake of a shift of strategy in the late 1990s and early 2000s and the decision to develop a strong agenda for sustainable development, BRECO was awarded and received considerable media coverage on several occasions for its 'green' responsiveness. The company reflects what Wehrmeyer et al. (2009) refer to as the changing UK business cultures in the light of the climate change challenge. As such, the case meets the criteria for en extreme or "polar type" (in the sense of high performing) case; one in which the process of theoretical interest is transparently observable and stands out from other cases (Eisenhardt, 1989, p. 537; Eisenhardt and Graebner, 2007, p. 27). I conducted twelve in-depth interviews with six managers: CEO, Operations/HR Director, Head of Marketing, Head Brewer, Sales Director, and Retail Director; in order to understand how these managers perceive, and respond to, environmental issues in their dayto-day business activities ${ }^{6}$. In line with the explanation building method (Yin, 2003), each informant was interviewed twice (March 2011 and November 2011). Annual reports, press articles and BRECO's web site were consulted to examine and cross-check the qualitative interview data. To increase empirical validity, a draft of the case study write-up was circulated to interviewees-as suggested by Yin (2003). Whenever feedback was received, they did not generate major amendments to the inferences made in the study. A grounded theory approach (Glaser, 2001) was adopted to identify and express the patterns of 
compatibility that emerge and how they are grounded in managers' meaning-in-use. The development of inductive data analysis principles is documented as part of the research (see Table 2). The table illustrates the logic of induction with reference to both the interpretation of patterns and the number of occurrences of these patterns in empirical data.

[Insert Table 2 about here]

Trade-off. As opposed to businesses who perceive green as a transient strategy and are, thereof, reluctant to instigate green improvements (Hahn et al., 2010; McCrea, 2010), the findings show a willingness from BRECO to act upon trade-offs. Consistent with Porter and van der Linde (1995b), the strategic focus is on continuous green innovation and improvement capabilities. For example, the company is currently taking steps towards the use of green gas (also called bio methane) to fuel the fleet of transport vehicles. The use of green gas is interpreted to constitute a form of synergistic improvement in logistic operations. The effect will be the mitigation of trade-offs between distribution/logistics and the environmental integrity goal.

The analysis indicates that a reinforcement of trade-off effects is predicted by BRECO; the cause of which rests on an increase in business activities and concomitant development decisions. Development initiatives will provoke a rise in total energy usage, notably due to longer opening hours of stores and intensified distribution processes. In 2010, BRECO installed a distillery and began the production of Gin, Vodka and Whiskey. These development decisions, together with more extreme weather conditions (especially at the beginning and end of the year), are expected to generate a higher carbon footprint. Yet again, BRECO strives to control and cap its energy usage. For example, solar panels are expected to produce a sufficient amount of energy to run the distribution centre and the bio digester.

A number of trade-offs are discussed to require further financial investment. They principally relate to bottle manufacture and brewing process. Regarding bottle manufacture, the findings suggest that BRECO looks to further the process of reducing the weight of glass bottles. However, the moulds needed to produce lighter bottles are deemed too expensive. As far as the brewery is concerned, the fermentation process is found to be a strong carbon emitter. Yet again, the equipment needed to capture and clean up $\mathrm{CO}_{2}$ emissions is deemed too expensive. This links back to the observation of Robèrt (2002) that energy systems (or new technology) are usually expensive and the transition to new energy systems cannot be

*Postprint of : Martinez, F. (2014). Corporate strategy and the environment: Towards a fourdimensional compatibility model for fostering green management decisions. Corporate Governance: The International Journal of Business in Society, 14(5), 607-636. 
made until they are fully developed. The lack of adapted filling stations, for instance, will limit the usage of bio-methane.

Ambidexterity. The activities of BRECO in favour of the environment are not limited to interventions on issues that have a direct impact on the business. ESR includes philanthropic initiatives which, by essence, are not intended to provide business benefits but to demonstrate the company's stakeholder engagement. Philanthropic (beach cleaning involving BRECO's staff) and partnership initiatives (in the management of food waste), as well as the development and marketing of a 'carbon neutral' beer, are found to be unrelated to BRECO's business performance. These environmental activities, although primarily ambidextrous to EFF-squared, may however contribute to consolidate the compatibility between green and EFF-squared in the long-term. That is:

- Beach cleaning illustrates the long-term aspiration of BRECO to achieve green/EFFsquared symbiosis, although it is not viewed to have a direct impact on BRECO's performance;

- Engagement in a joint venture company to exploit the anaerobic bio digestion plant is expected to improve the management of internal waste although it primarily aims to manage external food waste.

- The marketing impact of green credentials on consumption is found to be marginal (especially in the case of the 'carbon neutral beer'). However, these green credentials have not only generated improved commercial relationships and but they have also offered prospects for developing a greener product range.

Synergy. The findings indicate that the company anticipated the rise in the price of fossil fuels and the reinforcement of legislation around environmental issues. In line with Porter and van der Linde (1995a; 1995b) who praise the benefits of pollution prevention on business performance, this view gave rise to a conviction that preventive actions, in the form of synergistic improvements, ought to be found and exploited. The acquisitions of eco-efficient Brewing system and distribution centre are evidence that BRECO is able to exploit positive synergies between green and EFF-squared, with cost reduction being the main positive effect on business performance. For example, the new brewing system needs just 3.1 pints of water to produce a pint of beer. By contrast, the industry average in 2006-7 was 8 pints of water to make a pint of beer. In a similar vein, the construction of the new distribution depot was *Postprint of : Martinez, F. (2014). Corporate strategy and the environment: Towards a fourdimensional compatibility model for fostering green management decisions. Corporate Governance: The International Journal of Business in Society, 14(5), 607-636. 
executed with innovative materials now enabling the firm to save $50 \%$ on electricity and gas and constituting substantial cost savings. While consequently reducing cost, BRECO gained $4 \%$ market shares in a market that is down by $4.4 \%$.

Synergies are exploited on the supply side and packaging processes with the decision to introduce lighter weight beer bottles generating lower carbon footprint and better efficiencies in distribution processes. The lighter packaging alternative enabled to (i) reduce the pollution generated by the glass bottle manufacturing process; (ii) optimise the efficiency of logistic processes and minimise related $\mathrm{CO}_{2}$ emissions; and (iii) reduce the impact of products disposal on the environment.

The bio digestion plant contributes to the existing momentum of synergistic improvements. It not only produces gas that is transferred to the national grid but is conducive to greener waste management solutions. In term, all the waste and yeast generated by production processes will be put through the bio digester to produce energy. These synergies are found to emerge mostly in the form of green generating cost reductions.

Symbiosis. The findings place a strong emphasis on the role of strategic leadership in building strong stakeholder values and inspiring high concerns for environmental issues-a phenomenon highlighted in previous research by, e.g., Sully de Luque et al (2008); and Waldman and Siegel (2008). The idea of creating "a vision for the future" discussed by the CEO links back to the idea of aspiring to an eco-effectiveness business model "that sees commerce as the engine of change, and honours its need to function quickly and productively" (Braungart and McDonough, 2008, p. 150). The importance of decision-making and leadership corroborates the proposition that the degree of societal responsiveness stems from the way business actors interpret the EFF-squared concept and conceive, or not, green as a strategic priority. While green is not the 'reason for being' (Head of Marketing) of BRECO, it is emphasised as 'the right thing to do' (Operations Director)-thereby echoing the definition of effectiveness by Drucker (1954).

The firm's aspiration to create and sustain symbiotic green/EFF-squared compatibilities influenced investment decisions about infrastructures and technology development. This notably led to the construction of an 'environmentally friendly' distribution centre in 2006 and the installation of an eco-efficient brewing system in 2007. These investment decisions were driven equally by business sense and environmental credentials. The CEO highlights BRECO's value-oriented business model: 'We wanted to

*Postprint of : Martinez, F. (2014). Corporate strategy and the environment: Towards a fourdimensional compatibility model for fostering green management decisions. Corporate Governance: The International Journal of Business in Society, 14(5), 607-636. 
make some investments that we can be proud of and that are going to support our values of treading more lightly on the planet.'

In summary, the case study illustration demonstrates that ESR can be perceived and integrated in strategies and operations in varied forms. BRECO's managers converge on the idea that the Brewery aspires to achieve a symbiosis between green and EFF-squared. While green and business performance are found to produce a constant trade-off (in terms of carbon emissions), BRECO seeks continuous improvement to reduce and/or cap its environmental impact whilst engaging in ambidextrous activities. Green/EFF-squared synergies are not only exploited (notably in the form of eco-friendly infrastructures and technologies) but also explored to continuously strengthen the compatibility between green and EFF-squared; whether they relate to marketing (product design), production (fermentation process), distribution (bio-methane), retail or hotel activities. The implication is that BRECO's aspiration to become carbon neutral may come true when the positive environmental impact of synergies will reach or exceed the negative environmental impact of trade-off scenarios. A list of green and EFF-squared gaps captured in the research is provided in Table 3. The actions taken by BRECO in response to these gaps are synthesised and associated with green/EFF-squared compatibility dimensions.

[Insert Table 3 about here]

The average business firm faces many such challenges and might use the conceptual model to analyse its stance on these issues and perhaps help determine its ESR impacts, actions and response strategies. The model is particularly relevant to support the coordination of green initiatives and the development of integrated green/EFF-squared strategies that preserve business efficacy and financial performance. Managers would have a systematic framework for thinking through not only the environmental issues faced but also the managerial response patterns contemplated. The model could serve as a guide in formulating a firm's posture on various ecological issues. The net result could be more systematic attention being given to the whole realm of ESR. The application can be to consider the firm's activities related to ESR across the four compatibility dimensions, asking questions and looking for solutions. Questions might include:

- $\quad$ Do we aspire to an eco-effective business model (symbiosis)?

*Postprint of : Martinez, F. (2014). Corporate strategy and the environment: Towards a fourdimensional compatibility model for fostering green management decisions. Corporate Governance: The International Journal of Business in Society, 14(5), 607-636. 
- What are the trade-offs between green and EFF-squared? Can we envision opportunities for synergistic improvements?

- How do we generate opportunities for exploiting synergies? Are synergistic improvements effectively reducing major trade-offs?

- Where can green and EFF-squared complement each other? The idea of 'ambidexterity' is to accommodate to the fact that green may not necessarily be congruous, or incongruous, to business performance.

\section{Discussion}

The contribution of the compatibility framework is essentially made to the literature on environmental strategy management, evolved from an implicit and at most twodimensional (win-win and win-lose) conceptualisation of the relationship between business strategy and ESR into an explicit and multi-dimensionally grounded identification of processes and strategic challenges of ESR integration. The resulting model contributes to a better understanding of ESR as a strategic and moral concern to individuals acting on behalf of business organisations and a greater understanding of the linkages between ESR and business strategies and operations. As such, it better encompasses the variance in environmental responsiveness within corporations and adds depth to existing research on the link between ESR and business performance. I expand on the contributions of this article below.

\section{Theoretical contributions}

First, the four compatibility dimensions model complements existing approaches to the link between ESR and business strategy. Including the symbiotic and ambidextrous scenarios of compatibility offers an extension to the win-win and win-lose rational views that predominates in extant research. As a result, this paper contributes to an explanation of heterogeneity in the compatibility between ESR and business performance/strategy that brings us closer to specifying a contingent model of the business case for ESR. By integrating the strategic and cognitive drivers used in the decision-making process, the model helps explain the apparently context-dependent nature of business contributions to sustainable development (Barnett, 2007; Devinney, 2009). Instead of being based on clear, strategic criteria and 
unambiguous information (as some supporters of the separation thesis may argue), ESR decisions might be viewed as inherently uncertain, both in terms of how a decision is made and on what criteria it should be based, and in terms of possible benefits to the firm. While the potential strategic, reputational, or financial gains derived from ESR remain important elements of consideration (Margolis and Walsh, 2001), the pursuit of green/EFF-squared symbiosis and its cognitive variables might affect the way those considerations are evaluated, even though the manager may not be consciously aware of the effects of his/her environmental ethos on his/her decision making.

Second, the multi-level compatibility model complements existing research that primarily examined one scenario effect: either trade-off (e.g., Hahn et al., 2010) or win-win (e.g., Bansal, 2005). I argue that these effects are likely to be intertwined. For instance, winwin or synergistic actions reduce trade-offs (e.g., eco-efficient brewing system mitigate $\mathrm{CO}_{2}$ emissions in brewing operations). The identification of trade-offs is likely to trigger the exploration and exploitation of synergistic solutions (e.g., assessment of the environmental footprint of logistics at BRECO triggered the exploration of an alternative fuel solution for distribution vehicles: bio-methane). In this way, the model has properties in common with the cybernetic model of Roome (2012)-particularly in its emphasis on the capacity of managers to respond to a range of pressures, relationships and changes.

Third, I shed light on the specific mechanisms that might explain how ESR happens in business, becomes a strategically significant element, and ultimately improves the societal performance of corporations. Despite the differences in the action tendencies associated with various compatibility perceptions to which the case study application points, research on the link between business strategy-making and ESR thus far has focused primarily on investigating broad categories of win-win and win-lose scenarios. As a result, some business activities have been unnecessarily assigned valence despite their potential to be associated with different compatibility outcomes. As a case in point, studies focusing on green washing as a corporate marketing/reporting manoeuvre for commercial/reputational gains (Lyon and Maxwell, 2011) tend to overshadow the synergistic effect of marketing decisions aimed at reducing the environmental impact of packaging processes. BRECO's decision to reduce the weight of glass in bottling operations was essentially driven by the firm's marketing team. Studying the specific action tendencies associated with specific compatibility dimensions advances our understanding beyond broader categorisation based on one scenario of compatibility alone. In this vein, the compatibility framework might be well suited to explain

*Postprint of : Martinez, F. (2014). Corporate strategy and the environment: Towards a fourdimensional compatibility model for fostering green management decisions. Corporate Governance: The International Journal of Business in Society, 14(5), 607-636. 
the "non-linearity" of the relationship between corporate financial performance and corporate social performance captured by Brammer and Millington (2008, p. 1339). It also adds weight to the line of thinking that typologies/models which ascribe a specific level of responsiveness to an entire organisation (Buysse \& Verbeke, 2003; Greeno, 1993; Hass, 1996; Hunt \& Auster, 1990; Müller \& Koechlin, 1992; Newman, 1993; Roome, 1992) are less accurate than those seeking to accommodate different stages across the business. For example, the application of the four compatibility scenarios to the case of BRECO permits to highlight the two-fold response provoked by the practice of green marketing at BRECO; whether it translates into symbiosis aspiration or ambidexterity engagement.

\section{Practical implications}

The model also has practical value for managers, organisations, and their stakeholders. First, it might contribute to a reduction in the cynicism about the role businesses play in society stemming from the predominantly rational interpretation of ESR to which the separation thesis supported by Milton Friedman and its followers might have contributed. A consequence of the 'cynical' view is that corporate responses to environmental issues are bound to generate tangible win-win outcomes, with the realisation of cost reductions as a privileged pathway. In contrast, recognition of, e.g., the cognitive (symbiosis) and philanthropic (ambidexterity) elements of ESR is likely to engender a more heterogeneous assessment of the realities of ESR mechanisms and a more positive societal response by the firm. It also allows a less stringent interpretation of managerial discretion regarding ESR by acknowledging that while rational, strategic considerations are important, they might not constitute the overriding element in decisions. What is more, repeated acknowledgment and legitimatisation of the idea that operational and normative green/EFF-squared compatibilities are intertwined may affect the ordering of rational/strategic considerations and how they are evaluated in subsequent decisions, leading to a more sustainability-driven culture in the organisation. Future research work on the topic might also anticipate the fact that the compatibility approach may develop as settlements among top managers who seek to steer the environmental sensitivity of employees to be better aligned with the organisation's business objectives.

Second, by providing a comprehensive review of the existing literature along with firm specific examples, the study offers deepened knowledge of the construct of ESR. The

*Postprint of : Martinez, F. (2014). Corporate strategy and the environment: Towards a fourdimensional compatibility model for fostering green management decisions. Corporate Governance: The International Journal of Business in Society, 14(5), 607-636. 
result is a more nuanced understanding of the relationship between green and business performance and a broader perspective on the manifestation of ESR in business. This leads to a context-sensitive, and plausibly cross-cultural, compatibility framework for firms to assess, compose and inform decision-making processes. Whereas a considerable body of research has explained some of the variance in the scale of ESR, I know of no research in which scholars have tried to explain variance explicitly in the form of normative/cognitive and operational/pragmatic compatibility between green and business strategy, although scholarly research on the topic suggests that ESR is driven by a complex interplay of ethical and instrumental motives (Aguilera et al., 2007). Thus, the compatibility framework is likely to be associated with positive repercussions in the future, such as increased volunteering levels, greater employee contributions, and management-level legitimation through, for example, the structural development of ESR control processes and investment strategies.

Third, the model implies that by accounting for clearly defined compatibility dimensions and reflecting on how they relate, managers might trigger a 'maturation' journey (Zadek, 2004) across multiple levels in the organisation. For example, executive decisions influenced by environmental ethos (symbiosis aspiration) might enable the allocation of financial resources in synergistic assets such as eco-friendly production facilities, solar panels, water purifiers, bio-digesters, etc. This might be a signal strong enough to generate a collective momentum of sensitivity to environmental issues that feeds back into individuals' level of organisational identification and legitimises commitment to (ambidextrous) philanthropic activities (Muller et al., 2014). As a result, trade-offs between green and EFFsquared will be increasingly brought to light and mitigated.

\section{Conclusion}

This study opens up avenues for researchers to explore the results of an extended compatibility evaluation of ESR in business. As companies look forward with an eye to 2020 (EU, 2013), it is expected that attention will be given increasingly to measurement initiatives as well as theoretical development of sustainability management in general and ESR in particular. Future research could expand on the four-dimensional compatibility framework offered herein to elucidate the workings of additional actions associated with compatibility scenarios or to develop a more general multi-level model of green/EFF-squared compatibility in organisations. Scholars could also explore the impact of attitudes and approaches towards

*Postprint of : Martinez, F. (2014). Corporate strategy and the environment: Towards a fourdimensional compatibility model for fostering green management decisions. Corporate Governance: The International Journal of Business in Society, 14(5), 607-636. 
ethics and ESR that are rooted in different cultural traditions, social norms, economic conditions, regulatory institutions and business practices (Yang et al., 2013).

In this article, I took several steps toward understanding how ESR relates to business strategy in a contingent world, both in opposition to the separation thesis and beyond the predominant win-win(-win) and win-lose paradigms. While the compatibility approach is not intended to explain all pathways by which firms may elicit contingencies of relevance to ESR, I suggest the model paints a more complete and contextualised picture of ESR integration mechanisms in business. By incorporating two compatibility scenarios that have been largely ignored in research on corporate sustainability (symbiosis and ambidexterity), I further the business case for sustainability that helps reintegrate a sense of care for the welfare of the ecosystems as well as human societies in management theory and practice. To whatever extent the model presented here helps accomplish these objectives, it remains but a modest step toward (re)integrating ESR and economic/financial goals into a single corporate strategy.

\section{References}

Achabou, M. A., and Dekhili, S. (2013), "Luxury and sustainable development: Is there a match?", Journal of Business Research, Vol. 66 No. 10, pp. 1896-1903.

Ackoff, R. L. (1988), "A theory of practice in the social systems sciences", Systems Research, Vol. 5 No. 3, pp. 241-246.

Aguilera, R. V., Rupp, D. E., Williams, C. A., and Ganapathi, J. (2007), "Putting the S back in Corporate Social Responsibility: a multilevel theory of social change in organizations", Academy of Management Review, Vol. 32 No. 3, pp. 836-863.

Ardichvili, A., Jondle, D., Wiley, J., Cornacchione, E., Li, J., and Thakadipuram, T. (2012), "Ethical Cultures in Large Business Organizations in Brazil, Russia, India, and China", Journal of Business Ethics, Vol. 105 No. 4, pp. 415-428.

Audretsch, D. B. (1995), Innovation and Industry Evolution, Cambridge: MIT Press.

Aupperle, K. E., Carroll, A. B., and Hatfield, J. D. (1985), "An empirical examination of the relationship between corporate social responsibility and profitability", Academy of Management Journal, Vol. 28 No. 2, pp. 446-463.

Bansal, P. (2005), "Evolving sustainability: a longitudinal study of corporate sustainable development ", Strategic Management Journal, Vol. 26 No. 3, pp. 197-218.

*Postprint of : Martinez, F. (2014). Corporate strategy and the environment: Towards a fourdimensional compatibility model for fostering green management decisions. Corporate Governance: The International Journal of Business in Society, 14(5), 607-636. 
Barnett, M. L. (2007), "Stakeholder influence capacity and the variability of financial returns to corporate social responsibility", Academy of Management Review, Vol. 32 No. 3, pp. 794-816.

Boons, F., and Lüdeke-Freund, F. (2013), "Business models for sustainable innovation: stateof-the-art and steps towards a research agenda", Journal of Cleaner Production, Vol. 45 No. 0, pp. 9-19.

Bowie, N. E. (2013), "Varieties of Corporate Social Responsibility," in Business Ethics in the 21st Century, Springer Netherlands, pp. 91-112.

Boyle, E. J., Higgins, M. M., and Rhee, S. G. (1997), "Stock market reaction to ethical initiatives of defense contractors: theory and evidence", Critical Perspectives on Accounting Vol. 8 No. 6, pp. 541-561.

Brammer, S., and Millington, A. (2008), "Does it pay to be different? An analysis of the relationship between corporate social and financial performance", Strategic Management Journal, Vol. 29 No. 12, pp. 1325-1343.

Braungart, M., and McDonough, W. (2008), Cradle to Cradle: Re-Making the Way We Make Things, London: Jonathan Cape.

Browne, J., and Nuttall, R. 2013. "Beyond corporate social responsibility: integrated external engagement," McKinsey\&Company.

Burns, T., and Stalker, G. M. (1961), The Management of Innovation, London: Tavistock.

Buysse, K., and Verbeke, A. (2003), "Proactive environmental strategies: A stakeholder management perspective", Strategic Management Journal, Vol. 24 No. 5, pp. 453470.

Campbell, J. L. (2007), "Why would corporations behave in socially responsible ways? an institutional theory of corporate social responsibility", Academy of Management Review, Vol. 32 No. 3, pp. 946-967.

Capra, F. (2002), The Hidden Connections: Integrating the Biological, Cognitive, and Social Dimensions of Life into a Science of Sustainability, New York, NY: Doubleday.

Carroll, A. B., and Shabana, K. M. (2010), "The Business Case for Corporate Social Responsibility: A Review of Concepts, Research and Practice", International Journal of Management Reviews, Vol. 12 No. 1, pp. 85-105.

Cho, D.-S. (1994), "A dynamic approach to international competitiveness: the case of Korea", Journal of Far Eastern Business, Vol. 1 No. 1, pp. 17-36.

*Postprint of : Martinez, F. (2014). Corporate strategy and the environment: Towards a fourdimensional compatibility model for fostering green management decisions. Corporate Governance: The International Journal of Business in Society, 14(5), 607-636. 
Cohen, W. M., and Levinthal, D. A. (1990), "Absorptive capacity: a new perspective on learning and innovation", Administrative Science Quarterly, Vol. 35 No. 1, pp. 128152.

Colby, S., Kingsley, T., and Whitehead, B. W. (1995), "The real green issue", McKinsey Quarterly, No. 2, pp. 132-143.

Cruz Machado, V., and Duarte, S. (Year), "Tradeoffs among paradigms in supply chain management", International Conference on Industrial Engineering and Operations Management, Dhaka, Bengladesh, 2010.

Cusumano, M. A. (1994), "The Limits of "Lean"", Sloan Management Review, Vol. 35 No. 4, pp. 27-32.

Delmas, M. A., Etzion, D., and Nairn-Birch, N. (2013), "Triangulating environmental performance: what do corporate social responsibility ratings really capture?", Academy of Management Learning \& Education, Vol. 12 No. 3, pp. 255-267.

Deutsch, M. (1968), "The effects of cooperation and competition upon group processes," in Group dynamics, D. Cartwright and A. Zander (eds.), Harper \& Row: New York, pp. 461-482.

Devinney, T. M. (2009), "Is the socially responsible corporation a myth? The good, the bad, and the ugly of Corporate Social Responsibility", Academy of Management Perspectives, Vol. 23 No. 2, pp. 44-56.

Dienhart, J. W. (2008), "The separation thesis: perhaps nine lives are enough. A reponse to Joakim Sandberg", Business Ethics Quarterly, Vol. 18 No. 4, pp. 555-559.

DiMaggio, P. J., and Powell, W. W. (1983), "The iron cage revisited: institutional isomorphism and collective rationality in organizational fields", American Sociological Review, Vol. 48 No. 2, pp. 147-160.

Dixon-Fowler, H., Slater, D., Johnson, J., Ellstrand, A., and Romi, A. (2012), "Beyond "Does it Pay to be Green?" A Meta-Analysis of Moderators of the CEP-CFP Relationship", Journal of Business Ethics, No. 1-14.

Drucker, P. F. (1954), The Practice of Management, New York: Harper \& Row Publishers, Inc.

Duncan, R. B. (1976), "The ambidextrous organization: deseigning dual structures for innovation," in The management of organization, R. H. Kilmann, L. R. Pondy and D. Slevin (eds.), North-Holland: New York, pp. 167-188.

*Postprint of : Martinez, F. (2014). Corporate strategy and the environment: Towards a fourdimensional compatibility model for fostering green management decisions. Corporate Governance: The International Journal of Business in Society, 14(5), 607-636. 
Dutta, S., Lawson, R., and Marcinko, D. (2012), "Paradigms for Sustainable Development: Implications of Management Theory", Corporate Social Responsibility and Environmental Management, Vol. 19 No. 1, pp. 1-10.

Dwyer, R. J. (2009), ""Keen to be green" organizations: a focused rules approach to accountability", Management Decision, Vol. 47 No. 7, pp. 1200-1216.

Dyllick, T., and Hockerts, K. (2002), "Beyond the business case for corporate sustainability", Business Strategy and the Environment, Vol. 11 No. 2, pp. 130-141.

Eccles, R. G., Ioannou, I., and Serafeim, G. 2011. "The impact of a corporate culture of sustainability on corporate behavior and performance," Harvard Business School.

Eisenhardt, K. M. (1989), "Building theories from case study research", Academy of Management Review, Vol. 14 No. 4, pp. 532-550.

Eisenhardt, K. M., and Graebner, M. E. (2007), "Theory building from cases: opportunities and challenges", Academy of Management Journal, Vol. 50 No. 1, pp. 25-32.

Elkington, J. (2004), "Enter the triple bottom line," in The triple bottom line: does it all add up? Assessing the sustainability of Business and CSR, A. Henriques and J. Richardson (eds.), Earthscan: London, pp. 1-16.

Etzion, D. (2007), "Research on Organizations and the Natural Environment, 1992-Present: A Review", Journal of Management, Vol. 33 No. 4, pp. 637-664.

EU 2013. "Horizon 2020: the framework programme for research and innovation," European Commission, Brussels.

Fooks, G., Gilmore, A., Collin, J., Holden, C., and Lee, K. (2013), "The Limits of Corporate Social Responsibility: Techniques of Neutralization, Stakeholder Management and Political CSR", Journal of Business Ethics, Vol. 112 No. 2, pp. 283-299.

Friedman, M. (1970), "The social responsibility of business is to increase its profits," in The New York Times Magazine, The New York Times Company, pp. 32, 33, 122, 124, 126.

Garriga, E., and Melé, D. (2004), "Corporate Social Responsibility Theories: Mapping the Territory", Journal of Business Ethics, Vol. 53 No. 1, pp. 51-71.

Ghoshal, S. (2005), "Bad management theories are destroying good management practices", Academy of Management Learning \& Education, Vol. 4 No. 1, pp. 75-91.

Ginsberg, A., and Venkatraman, N. (1985), "Contingency perspectives of organisational strategy: a critical review of the empirical research", Academy of Management Review, Vol. 10 No. 3, pp. 421-434.

*Postprint of : Martinez, F. (2014). Corporate strategy and the environment: Towards a fourdimensional compatibility model for fostering green management decisions. Corporate Governance: The International Journal of Business in Society, 14(5), 607-636. 
Gladwin, T., Kennelly, J., and Krause, T. (1995), "Shifting paradigms for sustainable development: Implications for management theory and research", Academy of Management Review, Vol. 20 No. 4, pp. 878-907.

Glaser, B. (2001), The Grounded Theory Perspective: Conceptualization Contrasted With Description, Mill Valley, CA: Sociology Press.

Goerner, S. J., Lietaer, B., and Ulanowicz, R. E. (2009), "Quantifying economic sustainability: implications for free-enterprise theory, policy and practice", Ecological Economics, Vol. 69 No. 1, pp. 76-81.

Gond, J.-P., and Crane, A. (2010), "Corporate Social Performance Disoriented: Saving the Lost Paradigm?", Business \& Society, Vol. 49 No. 4, pp. 677-703.

Greeno, J. L. (1993), "Environmental excellence: meeting the challenge", Arthur D. Little Prism, Vol. Third Quarter No. 13-31.

Guerard, J. B. J. (1997), "Is there a cost to being socially responsible in investing?", Journal of Investing, Vol. 6 No. 2, pp. 11-18.

Gulati, R. (2007), "Silo busting: How to execute on the promise of customer focus", Harvard Business Review, Vol. 85 No. 5, pp. 98-108.

Hahn, T., Figge, F., Pinkse, J., and Preuss, L. (2010), "Trade-Offs in Corporate Sustainability: You Can't Have Your Cake and Eat It", Business Strategy and the Environment, Vol. 19 No. 4, pp. 217-229.

Hambrick, D. C., and Mason, P. A. (1984), "Upper echelons: The organization as a reflection of its top managers", Academy of Management Review, Vol. 9 No. 2, pp. 193-206.

Harris, J. D., and Freeman, R. E. (2008), "The impossibility of the separation thesis ", Business Ethics Quarterly, Vol. 18 No. 4, pp. 541-548.

Hart, S. L. (1995), "A natural resource-based view of the firm", Academy of Management Review, Vol. 20 No. 4, pp. 986-1014.

Hart, S. L. (1997), "Beyong Greening: Strategies for a Sustainable World", Harvard Business Review, Vol. 75 No. 1, pp. 66.

Hass, J. L. (1996), "Environmental ('green') management typologies: an evaluation, operationalization and empirical development", Business Strategy and the Environment, Vol. 5 No. 2, pp. 59-68.

Hofferberth, M., Bruhl, T., Burkart, E., Fey, M., and Peltner, A. (2011), "Multinational enteprises as "social actors" - Constructivist explanations for corporate social

*Postprint of : Martinez, F. (2014). Corporate strategy and the environment: Towards a fourdimensional compatibility model for fostering green management decisions. Corporate Governance: The International Journal of Business in Society, 14(5), 607-636. 
responsibility", Global Society: Journal of Interdisciplinary International Relations, Vol. 25 No. 2, pp. 205-226.

Huczynsky, A. A., and Buchanan, D. A. (2007), Organizational Behaviour, Harlow: Pearson Education Ltd.

Hunt, C. B., and Auster, E. R. (1990), "Proactive environmental management: avoiding the toxic trap", Sloan Management Review, Vol. 31 No. 2, pp. 7-18.

Jabbour, C. J. C., Santos, F. C. A., and Nagano, M. S. (2008), "Environmental management system and human resource practices: is there a link between them in four Brazilian companies?", Journal of Cleaner Production, Vol. 16 No. 17, pp. 1922-1925.

Jensen, T., and Sandström, J. (2013), "In defence of stakeholder pragmatism", Journal of Business Ethics, Vol. 114 No. 2, pp. 225-237.

Kaplan, S., and Orlikowski, W. 2007. "Projecting the future: the temporality of strategymaking," MIT working paper.

King, A. A., and Lenox, M. J. (2001a), "Does it really pay to be green? An empirical study of firm environmental and financial performance", Journal of Industrial Ecology, Vol. 5 No. 1, pp. 105-116.

King, A. A., and Lenox, M. J. (2001b), "Lean and Green? An empirical examination of the relationship between lean production and environmental performance", Production and Operations Management, Vol. 10 No. 3, pp. 244-256.

Kollman, T., and Stockman, C. (2008), "Corporate Entrepreneurship," in 21st Century Management: A Reference Handbook, C. Wanker (ed.), Sage: London, pp. 11-21.

Kurucz, E., Colbert, B., and Wheeler, D. (2008), "The business case for corporate social responsibility," in The Oxford Handbook of Corporate Social Responsibility, A. Crane, A. McWilliams, D. Matten, J. Moon and D. Siegel (eds.), Oxford University Press: Oxford, pp. 83-112.

Lawrence, P., and Lorsch, J. (1967), Organizations and environment: managing differentiation and integration, Homewood, IL: Irwin.

Levitt, T. (2004), "Marketing Myopia", Harvard Business Review, Vol. 82 No. 7/8, pp. 138149.

Lewin, K. (1951), "Behavior and Development as a Function of the Total Situation," in Field Theory in Social Science, C. D. (ed.), Harper \& Brothers: New York.

*Postprint of : Martinez, F. (2014). Corporate strategy and the environment: Towards a fourdimensional compatibility model for fostering green management decisions. Corporate Governance: The International Journal of Business in Society, 14(5), 607-636. 
Lohmann, L. (2009), "Toward a different debate in environmental accounting: The cases of carbon and cost-benefit", Accounting, Organizations and Society, Vol. 34 No. 3-4, pp. 499-534.

Lorenzo-Molo, C. F., and Udani, Z. A. S. (2013), "Bringing Back the Essence of the "S" and "R" to CSR: Understanding the Limitations of the Merchant Trade and the White Man's Burden", Journal of Business Ethics, Vol. 117 No. 1, pp. 123-136.

Lyon, T. P., and Maxwell, J. W. (2011), "Greenwash: Corporate Environmental Disclosure under Threat of Audit", Journal of Economics \& Management Strategy, Vol. 20 No. 1, pp. 3-41.

Malik, M. (2014), "Value-Enhancing Capabilities of CSR: A Brief Review of Contemporary Literature", Journal of Business Ethics, No. 1-20.

Margolis, J. D., Elfenbein, H. A., and Walsh, J. P. 2007. "Does it pay to be good? A metaanalysis and redirection of research on the relationship between corporate social and financial performance," Harvard Business School.

Margolis, J. D., Elfenbein, H. A., and Walsh, J. P. 2009. "Does it pay to be good... And does it matter? A meta-analysis of the relationship between corporate social and financial performance," Harvard University.

Margolis, J. D., and Walsh, J. P. (2001), People and profits? The search for a link between a company's social and financial performance, Mahwah, NJ: Lawrence Erlbaum Associates.

Margolis, J. D., and Walsh, J. P. (2003), "Misery loves companies: rethinking social initiatives by business", Administrative Science Quarterly, Vol. 48 No. 2, pp. 268-305.

Martinez, F., Vazquez-Brust, D., Peattie, K., and Zokaei, K. (2012), "Achieving greener growth: a business perspective for proactive commitment," in Green Growth: Managing the transition to a Sustainable Economy, D. Vazquez-Brust and J. Sarkis (eds.), Springer: Dordrecht, Heidelberg, New York, London, pp. 191-212.

Mazurkiewicz, P. 2004. "Corporate environmental responsibility: is a common CSR framework possible?," World Bank working paper.

McCrea, B. (2010), "Why "Green" equals good business", Supply Chain Management Review, Vol. 14 No. 2, pp. S56-S60.

McNulty, E. J., and Davis, R. (2010), "Should the C-Suite have a "Green" Seat?", Harvard Business Review, Vol. 88 No. 12, pp. 133-137.

*Postprint of : Martinez, F. (2014). Corporate strategy and the environment: Towards a fourdimensional compatibility model for fostering green management decisions. Corporate Governance: The International Journal of Business in Society, 14(5), 607-636. 
Melé, D., Argandoña, A., and Sanchez-Runde, C. (2011), "Facing the Crisis: Toward a New Humanistic Synthesis for Business", Journal of Business Ethics, Vol. 99 No. 1, pp. 14.

Mouzas, S. (2006), "Efficiency versus effectiveness in business networks", Journal of Business Research, Vol. 59 No. 10-11, pp. 1124-1132.

Muller, A. R., Pfarrer, M. D., and Little, L. M. (2014), "A theory of collective empathy in corporate philanthropy decisions", Academy of Management Review, Vol. 39 No. 1, pp. 1-21.

Müller, K., and Koechlin, D. (1992), "Environmentally conscious management," in Green Business Opportunities: the Profit Potential, D. Koechlin and K. Müller (eds.), Pitman: London.

Murphy, R. (2004), "Disaster of sustainability: The dance of human agents with nature's actants", Canadian Review of Sociology and Anthropology, Vol. 41 No. 249-266.

Newman, J. C. (1993), "Opportunity knocks, and leaders answer", Directors and Boards, Vol. 18 No. 1, pp. 32-48.

O'Reilly, C. A., and Tushman, M. L. (2008), "Ambidexterity as a dynamic capability: Resolving the innovator's dilemma", Research in Organizational Behavior, Vol. 28 No. $185-206$.

Orlitzky, M. (2005), "Social responsibility and financial performance: Trade-off or virtuous circle?", University of Auckland Business Review, Vol. 7 No. 1, pp. 37-43.

Orlitzky, M., Schmidt, F. L., and Rynes, S. L. (2003), "Corporate social and financial performance: a meta-analysis", Organisation Studies, Vol. 24 No. 3, pp. 403-441.

Pane Haden, S. S., Oyler, J. D., and Humphreys, J. H. (2009), "Historical, practical, and theoretical perspectives on green management: An exploratory analysis", Management Decision, Vol. 47 No. 7, pp. 1041-1055.

Patagonia (2005), "Patagonia's common threads garment recycling progam: a detailed analysis."

Peattie, K. (2001), "Towards Sustainability: The Third Age of Green Marketing", The Marketing Review, Vol. 2 No. 2, pp. 129-146.

Peattie, K., and Charter, M. (1997), "Green Marketing," in The Marketing Book, M. Baker and S. Hart (eds.), Elsevier: Burlington, pp. 726-757.

Pedersen, E. (2010), "Modelling CSR: How Managers Understand the Responsibilities of Business Towards Society", Journal of Business Ethics, Vol. 91 No. 2, pp. 155-166.

*Postprint of : Martinez, F. (2014). Corporate strategy and the environment: Towards a fourdimensional compatibility model for fostering green management decisions. Corporate Governance: The International Journal of Business in Society, 14(5), 607-636. 
Petrick, J. A., and Scherer, R. F. (2003), "The Enron scandal and the neglect of management integrity capacity", Mid - American Journal of Business, Vol. 18 No. 1, pp. 37-49.

Pfeffer, J. (2010), "Building Sustainable Organizations: The Human Factor", Academy of Management Perspectives, Vol. 24 No. 1, pp. 34-45.

b, M. E. (1985), Competitive Advantage: Creating and Sustaining Superior Performance, New York \& London: Press Ganey Associates.

Porter, M. E., and Kramer, M. R. (2006), "Strategy and society: the link between competitive advantage and corporate social responsibility", Harvard Business Review, Vol. 84 No. 12, pp. 78-92.

Porter, M. E., and Kramer, M. R. (2011), "Creating shared value: How to reinvent capitalism and unleash a wave of innovation and growth", Harvard Business Review, Vol. 89 No. 1/2, pp. 62-77.

Porter, M. E., and van der Linde, C. (1995a), "Green and competitive: ending the stalemate", Harvard Business Review, Vol. 73 No. 5, pp. 120-134.

Porter, M. E., and van der Linde, C. (1995b), "Toward a new conception of the environmentcompetitiveness relationship", Journal of Economic Perspectives, Vol. 9 No. 4, pp. 97-118.

Pujari, D., Peattie, K., and Wright, G. (2004), "Organizational antecedents of environmental responsiveness in industrial new product development", Industrial Marketing Management, Vol. 33 No. 5, pp. 381-391.

Pursey, P. M., and Heugens, A. R. (2006), "Environmental issue management: towards a multi-level theory of environmental management competence", Business Strategy and the Environment, Vol. 15 No. 6, pp. 363-376.

Reddin, W. J. (1970), Managerial Effectiveness, New York: McGraw Hill.

Reinhardt, F. L., and Stavins, R. N. (2010), "Corporate social responsibility, business strategy, and the environment", Oxford Review of Economic Policy, Vol. 26 No. 2, pp. 164-181.

Robèrt, K.-H. (2002), The Natural Step story: Seeding a quiet revolution, Gabriola Island, Canada: New Society Publishers.

Roddick, A. (2000), Business as Unusual: The Triumph of Anita Roddick, Bath, UK: The Bath Press.

Roddick, A. (2003), A revolution in Kindness, USA: Anita Roddick Books.

*Postprint of : Martinez, F. (2014). Corporate strategy and the environment: Towards a fourdimensional compatibility model for fostering green management decisions. Corporate Governance: The International Journal of Business in Society, 14(5), 607-636. 
Roome, N. (1992), "Developing environmental management strategies", Business Strategy and the Environment, Vol. 1 No. 1, pp. 11-24.

Roome, N. (2012), "A cybernetic model of corporate responsibility: sensing changes in business and society", International Journal of Technology Management, Vol. 60 No. $1 / 2$, pp. 4-22.

Rothenberg, S., Pil, F. K., and Maxwell, J. (2001), "Lean, green, and the quest for superior environmental performance", Production and Operations Management, Vol. 10 No. 3, pp. 228-243.

Russo, M. V., and Fouts, P. A. (1997), "A resource-based perspective on corporate environmental performance and profitability", Academy of Management Journal, Vol. 40 No. 3, pp. 534-559.

Salzmann, O., Ionescu-Somers, A., and Steger, U. (2005), "The business case for corporate sustainability: literature review and research options", European Management Journal, Vol. 23 No. 1, pp. 27-36.

Sawyer, A. G., and Peter, J. P. (1983), "The significance of statistical significance tests in marketing research", Journal of Marketing Research, Vol. 20 No. 2, pp. 122-133.

Schaltegger, S., Lüdeke-Freund, F., and Hansen, E. G. (2012), "Business cases for sustainability: the role of business model innovation for corporate sustainability", International Journal of Innovation and Sustainable Development, Vol. 6 No. 2, pp. 95-119.

Scholl, J. (2013), Inclusive business models as a key driver for social innovation, London: Springer.

Schreck, P. (2011), "Reviewing the Business Case for Corporate Social Responsibility: New Evidence and Analysis", Journal of Business Ethics, Vol. 103 No. 2, pp. 167-188.

Shelton, R. (1994), "Hitting the green wall: why corporate programs get stalled", Corporate Environmental Strategy, Vol. 2 No. 2, pp. 5-11.

Siegel, D. S. (2009), "Green management matters only if it yields more green: an economic/strategic perspective", Academy of Management Perspectives, Vol. 23 No. 3, pp. 5-16.

Siegel, D. S., and Vitaliano, D. F. (2007), "An empirical analysis of the strategic use of corporate social responsibility", Journal of Economics and Management Strategy, Vol. 16 No. 3, pp. 773-792.

*Postprint of : Martinez, F. (2014). Corporate strategy and the environment: Towards a fourdimensional compatibility model for fostering green management decisions. Corporate Governance: The International Journal of Business in Society, 14(5), 607-636. 
Sigglekow, N., and Levinthal, D. A. (2003), "Temporarily divide to conquer: centralization, decentralization and reintegrated organizational approaches to exploration and adaptation", Organization Science, Vol. 14 No. 6, pp. 650-669.

Simons, D., and Mason, R. (2003), "Lean and green: 'doing more with less'", International Commerce Review: ECR Journal, Vol. 3 No. 1, pp. 84-91.

Smith, W. K., and Lewis, M. W. (2011), "Toward a theory of paradox: a dynamic equilibrium model of organizing", Academy of Management Review, Vol. 36 No. 2, pp. 381-403.

Starik, M., and Kanashiro, P. (2013), "Toward a Theory of Sustainability Management: Uncovering and Integrating the Nearly Obvious", Organization \& Environment, No.

Sully de Luque, M., Washburn, N. T., Waldman, D. A., and House, R. J. (2008), "Unrequired profit: how stakeholder and economic values relate to subordinates' perceptions of leadership and firm performance", Administrative Science Quarterly, Vol. 53 No. 4, pp. 626-654.

Sun, W., and Cui, K. (2014), "Linking corporate social responsibility to firm default risk", European Management Journal, Vol. 32 No. 2, pp. 275-287.

Swanson, D. L. (1999), "Toward an integrative theory of business and society: a research strategy for corporate social performance", Academy of Management Review, Vol. 24 No. 3, pp. 506-521.

Tinsley, S. (2002), "EMS models for business strategy development", Business Strategy and the Environment, Vol. 11 No. 6, pp. 376-339.

Tornatzky, L. G., and Klein, K. J. (1982), "Innovation characteristics and innovation adoption-implementation: a meta-analysis of findings", IEEE Transactions on Engineering Management, Vol. 29 No. 1, pp. 28-45.

Tushman, M. L., and O'Reilly, C. A. (1996), "Ambidextrous organizations: managing evolutionary and revolutionary change", California Management Review, Vol. 38 No. 4, pp. 8-30.

Tushman, M. L., and O'Reilly, C. A. (1997), Winning through innovation: A practical guide to leading organizational change and renewal, Boston, MA: Harvard University Press.

Tushman, M. L., and Romanelli, E. (1985), "Organizational evolution: a metamorphosis model of convergence and reorientation", Research in Organizational Behavior, Vol. 7 No. 171-222.

*Postprint of : Martinez, F. (2014). Corporate strategy and the environment: Towards a fourdimensional compatibility model for fostering green management decisions. Corporate Governance: The International Journal of Business in Society, 14(5), 607-636. 
Ullman, A. A. (1985), "Data in search of a theory: a critical examination of the relationships among the social disclosure, and economic performance of U.S. firms", Academy of Management Review, Vol. 10 No. 3, pp. 540-557.

Usunier, J.-C., Furrer, O., and Furrer-Perrinjaquet, A. (2011), "The perceived trade-off between corporate social and economic responsibility: A cross-national study", International Journal of Cross Cultural Management : CCM, Vol. 11 No. 3, pp. 279.

Valente, M. (2010), "Demystifying the struggle of private sector paradigmatic change: business as an agent in a complex adaptive system", Business and Society, Vol. 49 No. 3, pp. 439-476.

Valente, M. (2012), "Theorizing firm adoption of sustaincentrism", Organization Studies, Vol. 33 No. 4, pp. 563-591.

Valor, C. (2008), "Can consumers buy responsibly? Analysis and solutions for market failures", Journal of Consumer Policy, Vol. 31 No. 3, pp. 315-326.

Van de Ven, A. H., Ganco, M., and Hinings, C. R. (2013), "Returning to the Frontier of Contingency Theory of Organizational and Institutional Designs", The Academy of Management Annals, Vol. 7 No. 1, pp. 393-440.

Vazquez-Brust, D., Plaza Ubeda, J., and Natenzon, C. (2009), "Environment and vulnerability: the necessity for adaptation and entrepreneurship and the key role of stakeholders," in Management Education for Global Sustainability, J. Wanker and J. Stoner (eds.), IAP Verma: Charlotte, NC, pp. 175-206.

Waddock, S. A., and Graves, S. (1997), "The corporate social performance - financial performance link", Strategic Management Journal, Vol. 18 No. 4, pp. 303-319.

Waldman, D. A., and Siegel, D. S. (2008), "Defining the socially responsible leader", The Leadership Quarterly, Vol. 19 No. 1, pp. 117-131.

Walley, N., and Whitehead, B. W. (1994), "It's not easy being green", Harvard Business Review, Vol. 72 No. 3, pp. 46-52.

Wehrmeyer, W., Leitner, A., and Woodman, P. 2009. "Lean and green: leadership for a lowcarbon future," Chartered Management Institute, London.

Weitzel, W., and Jonsson, E. (1989), "Decline in Organizations: A Literature Integration and Extension", Administrative Science Quarterly, Vol. 34 No. 1, pp. 91-109.

Williamson, O. E. (1985), The Economic Institutions of Capitalism: Firms, Markets, Relational Contracting, New York, NY: The Free Press.

*Postprint of : Martinez, F. (2014). Corporate strategy and the environment: Towards a fourdimensional compatibility model for fostering green management decisions. Corporate Governance: The International Journal of Business in Society, 14(5), 607-636. 
Woodward, J. (1965), Industrial organization: theory and practice, London: Oxford University Press.

Wright, P., and Ferris, S. P. (1997), "Agency conflict and corporate strategy: the effect of divestment on corporate value", Strategic Management Journal, Vol. 18 No. 1, pp. 77 83.

Yang, N., Colvin, C., and Wong, Y.-Y. (2013), "Navigating corporate social responsibility components and strategic options: the IHR perspective", Academy of Strategic Management Journal, Vol. 12 No. 1, pp. 39-58.

Yin, R. K. (2003), Case Study Research: Design and Methods, Thousand Oaks, CA: Sage.

Young, W., and Tilley, F. (2006), "Can businesses move beyond efficiency? The shift toward effectiveness and equity in the corporate sustainability debate", Business Strategy and the Environment, Vol. 15 No. 6, pp. 402-415.

Zadek, S. (2004), "The Path to Corporate Responsibility", Harvard Business Review, Vol. 82 No. 12 , pp. 125-132.

\footnotetext{
${ }^{1}$ Hart (1997, p. 67) provides information about the historical evolution of environmental management strategy from the 1960s (state of ESR denial) to the 1990s (state of ESR acceptance). Ultimately, the interconnectedness of social and environmental challenges from a sustainability perspective means that attempts to treat environmental and social responsibilities as separate are unhelpful.

${ }^{2}$ I follow Mazurkiewicz's definition of green (or ESR) as "the duty to cover the environmental implications of the company's operations, products and facilities; eliminate waste and emissions; maximise the efficiency and productivity of its resources; and minimise practices that might adversely affect the enjoyment of the country's resources by future generations" (2004, p. 53).

${ }^{3}$ This conclusion is drawn by Rothenberg et al. (2001) on two surveys of 31 automobile assembly plants in North America and Japan, which contain information on manufacturing practice and environmental performance, as well as in-depth interviews with 156 plant level employees at 17 assembly plants.

${ }^{4}$ Examples of such external costs include pollution and environmental degradation, such as global warming, acid rain, and deforestation. To a typical lumber producer or a farmer, the forest has only an economic value. However, from a societal perspective, forests also have recreational, existence, and biodiversity value (e.g., witness the ongoing controversy surrounding the preservation of the rainforest in South America).

${ }^{5}$ Since its foundation, BRECO went through continuous and significant enlargement and modernisation with major changes occurring in the 1970s (when the process of enlargement began) and in 2006-7. In 1990, the company founded a charity to celebrate its centenary as a public company; the objective being to support worthwhile causes within a 25 -mile radius of the site by utilising a percentage of the company's annual profit. Another milestone was the installation of new fermenting vessels in 2001-3 in order to renovate BRECO's production systems and cope with increasing demand. Consistent with the firm's focus on socially responsible development, the brewhouse was completely re-equipped in 2006-7 making it one of the most energy efficient in Europe. The firm also initiated a project to build a new distribution centre and expand its business with the purchase of land in a neighbouring town at the beginning of 2004. Since its installation, the new 'eco-efficient' distribution centre provided substantial improvements in distribution activities in terms of both ESR and business efficiency. BRECO is composed of four core business divisions: brewing operations, logistic operations and customer contact, the retail business and the hotel business. Brewing operations include brewing, brands/pubs and distribution. Logistic operations and customer contact are attached to Human Resource Management (HRM) and information technology. The retail business consists of shops, online business and mail order business. The final sample of six respondents covers all of these business functions; it includes the CEO,
}

*Postprint of : Martinez, F. (2014). Corporate strategy and the environment: Towards a fourdimensional compatibility model for fostering green management decisions. Corporate Governance: The International Journal of Business in Society, 14(5), 607-636. 
Operations Director (also responsible for HRM), Head of Marketing, Head Brewer, Sales Director and Retail Director.

${ }^{6}$ A semi-structured interview guide was used and the following 'generic' questions were asked to each interviewee: what is the mission of BRECO? What are the firm's core competencies? Can you describe your own responsibilities? What are the implications for the management of environmental issues? How does BRECO impact the environment? How can the company do better? How do you foresee the short-term and long-term future of the company?

*Postprint of : Martinez, F. (2014). Corporate strategy and the environment: Towards a fourdimensional compatibility model for fostering green management decisions. Corporate Governance: The International Journal of Business in Society, 14(5), 607-636. 